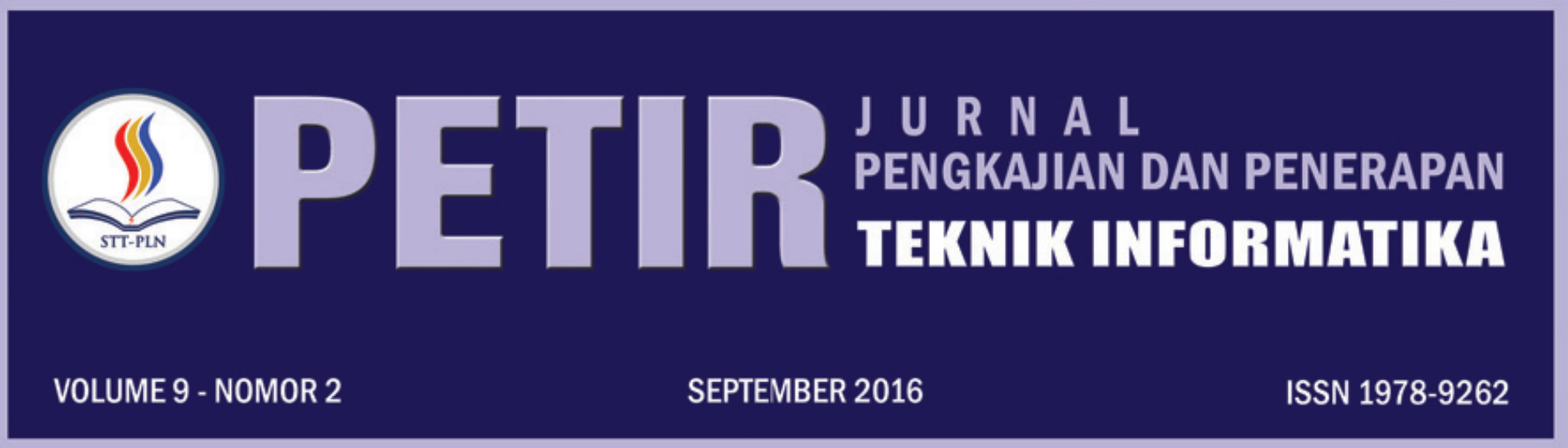

ANALISA SPASIAL UNTUK MELIHAT TINGKAT KESEJAHTERAAN MASYARAKAT DI PROVINSI BANTEN Muhamad Jafar Elly; Reza Pahlevi

PENENTUAN WILAYAH RAWAN PENYAKIT BERBASIS LINGKUNGAN DI JAKARTA TIMUR MENGGUNAKAN SISTEM INFORMASI GEOGRAFIS

Atiqah Meutia Hilda; Muhamad Jafar Elly; Windu Nugroho Cahyo Pamungkas

APLIKASI PENCARIAN USTADZ UNTUK WILAYAH DKI JAKARTA MENGGUNAKAN ALGORITMA HAVERSINE FORMULA BERBASIS ANDROID

Harni Kusniyati; Haries Fadhillah

PERENCANAAN ARSITEKTUR ENTERPRISE PERGURUAN TINGGI DENGAN PENDEKATAAN ENTERPRISE ARCHITECTURE PLANNING (EAP) (STUDI KASUS POLITEKNIK PIKSI GANESHA)

M. Farid Rifai

PERANCANGAN E-KATALOG PADA PERPUSTAKAAN DIGITAL STT-PLN BERBASIS WEB

Yessy Fitriani; Yasni Djamain; Risalatulina Dwi Kurniati

APLIKASI SISTEM GPS KEGIATAN OPERASIONAL PERSAMPAHAN DINAS PENGELOLAAN SAMPAH, PERTAMANAN DAN PEMAKAMAN (DP4) KOTA SUKABUMI

Yasmi Afrizal; Julian Chandra W
PERANCANGAN APLIKASI PENGOLAHAN DATA KAS BERBASIS ONLINE
(STUDI KASUS : KEMENTRIAN ' $X$ ')
Dian Hartanti; Lingga Desyanita

PERANCANGAN SISTEM INFORMASI PESERTA SERTIFIKASI

(Studi kasus LSP Piksi Ganesha)

Hendra Jatnika

RANCANG BANGUN APLIKASI SEC-WAY GUNA PENGINGAT BEPERGIAN DILENGKAPI INFO CUACA DAN CCTV JALAN RAYA LOKASI PILIHAN BERBASIS ANDROID STUDI KASUS DKI JAKARTA

Yasni Djamain; Intan Ratna Sari Yanti; Hari Wibowo

PREDIKSI PENERIMAAN SISWA BARU PADA MADRASAH ALIYAH AS-SAYAFI'IYAH 02 MENGGUNAKAN METODE TIME SERIES

Sarwo; Hermawan

PERANCANGAN SIMULASI MEDIA PEMBELAJARAN DENGAN METODE DIVISION REMAINDER UNTUK PENCARIAN ALAMAT RELATIF PADA PROSES PENEMPATAN DATA

Dewi Arianti Wulandari; Darma Rusjdi

ANALISIS SISTEM PENENTUAN LOKASI GANGGUAN JARINGAN DISTRIBUSI LISTRIK TERINTEGRASI GOOGLE MAP Abdul Haris; Herman Bedi Agtriadi

\begin{tabular}{|c|c|c|c|c|c|c|}
\hline \multirow{2}{*}{ 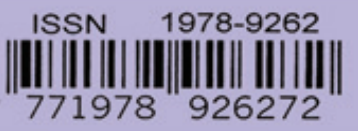 } & \multicolumn{6}{|c|}{ SEKOLAH TINGGI TEKNIK - PLN (STT-PLN) } \\
\hline & PETIR & VOL. 9 & NO. 2 & HAL. 89 - 166 & JAKARTA, SEPTEMBER 2016 & ISSN 1978-9262 \\
\hline
\end{tabular}




\title{
PERANCANGAN SIMULASI MEDIA PEMBELAJARAN DENGAN METODE DIVISION REMAINDER UNTUK PENCARIAN ALAMAT RELATIF PADA PROSES PENEMPATAN DATA
}

\author{
Dewi Arianti Wulandari,Skom.,MMSI ${ }^{1}$ dan Darma Rusjdi, ST.,MKom² \\ Jurusan Teknik Informatika STT-PLN \\ dewi ardari03@yahoo.com, drusjdi@yahoo.com
}

\begin{abstract}
Abstrak
Media pembelajaran merupakan salah satu media yang dapat membantu mahasiswa dalam memahami dan mengerti materi matakuliah. Dalam matakuliah sistem berkas ada materi tentang bagaimana menempatkan suatu data pada sebuah tabel. Materi tersebut adalah penggunaan teknik hashing dalam mencari alamat relatif dari suatu data. Dalam penerapan fungsi Hash untuk mencari alamat relatif terdapat kemungkinan beberapa data memiliki hasil fungsi Hash yang sama. Hal ini menyebabkan terjadinya tabrakan (collision) pada saat penempatan data. Tabrakan (collision) dapat diatasi dengan menggunakan beberapa strategi antara lain, Resolusi Linier (Linear Resolution), Overflow dan Double Hashing. Perancangan simulasi ini disusun yang dimulai dengan membuat konsep, design, material collecting, dan assembly. Pada tahap design terbagi menjadi empat tahapan yaitu tahapan perancangan flowchart proses aplikasi, rancangan hierarki menu aplikasi, rancangan tampilan menu utama dan rancangan alur proses perhitungan aplikasi.Aplikasi ini bertujuan untuk membantu dosen dalam mengajar sehingga mahasiswa dapat dengan mudah mengerti dan memahami materi tentang fungsi hash khususnya metode division remainder untuk mencari alamat relatif
\end{abstract}

Kata kunci : Hash search, pencarian relatif, perangkat pembelajaran, Division Remainder, Sistem Berkas

\begin{abstract}
Learning media is one medium that can help students understand the subject matter. No file system in the course material on how to put the data in a table. The material is the use of hashing technique in the search for the relative address of the data. In applying the hash function to find the relative address is probable some data have the same hash function results. This causes a collision (collision) at the time of placement data. Collision (collision) can be addressed by using multiple strategies, among others, Resolution Linear (Linear Resolution), and Double Hashing Overflow. The design of this simulation was organized which begins with the concept, design, material collecting, and assembly. At the design stage is divided into four stages, namely stages of the application process flowchart design, design app menu hierarchy, the design of the main menu display and design process flow aplikasi.Aplikasi calculation aims to assist lecturers in teaching so that students can easily understand and comprehend the material on the hash function particularly the division remainder method to find the relative address.
\end{abstract}

Keywords: Hash search, relative search, learning devices, Division Remainder, File Systems

\section{PENDAHULUAN}

\subsection{Latar Belakang Masalah}

Teknik hashing (scatter storage) meliputi suatu perhitungan aritmatika pada nilai kunci untuk menghasilkan satu bilangan bulat / integer. Bilangan bulat ini merupakan alamat relatif dimana nilai kunci disimpan di direktori. Direktori disimpan sebagai satu array.Pencarian (searching) merupakan pekerjaan yang sering kita lakukan dalam kehidupan sehari - hari. Dalam text editor, kita sering melakukan pekerjaan mencari kata, atau mencari suatu kata dan menggantikannya dengan kata yang lain, atau mencari kata tertentu dan menghitung frekuensi kemunculan kata tersebut dalam dokumen. Pada teknik hash atau dikenal dengan fungsi hash ada 5 fungsi yang umum digunakan yaitu Division Remainder, Truncation, Folding, Multiplication dan Mid Square. Pencarian relatif (Hash Search) menggunakan rumus tertentu untuk melakukan proses penempatan dan pencarian data. Pada saat ini sesuai dengan perkembangan di dunia teknologi informasi dimana segala sesuatunya dapat memudahkan seseorang dalam menyelesaikan suatu problem atau masalah , sehingga pada penelitian akan dibuat suatu aplikasi simulasi yang dapat memudahkan baik dari sisi dosen dalam menyampaikan materi sehingga suasana kelas dapat membuat mahasiswa tertarik dalam mengikuti perkuliahan dan mahasiswa dapat lebih mudah dalam memahami dan mengerti materi yang disampaikan karena adanya suatu media pembelajaran yang dilengkapi dengan simulasi perhitungan dan penempatan data ke dalam tabel.

\subsection{Rumusan Masalah}

Berdasarkan latar belakang permasalahan di atas maka dapat dibuat suatu rumusan masalah yaitu bagaimana membuat media pembelajaran dalam bentuk simulasi proses perhitungan dan penempatan data ke dalam suatu tabel . 


\subsection{Tujuan dan Manfaat}

Tujuan penelitian ini adalah untuk merancang media pembelajaran untuk mensimulasikan metode pencarian alamat relatif khususnya metode division remainder sebagai fasilitas pendukung dalam proses belajar mengajar.

Manfaat dari penelitian ini yaitu Membantu Dosen dalam menyampaikan materi tentang metode pencarian relatif agar mudah dipahami dan dimengerti oleh mahasiswa, khususnya untuk Matakuliah Sistem Berkas.

\section{LANDASAN TEORI}

\subsection{Study Literatur}

[1] Menurut Tejo Nurseto, 2011, Jurnal Ekonomi \& Pendidikan, Volume 8 Nomor 1, April 2011 yang berjudul Pembuatan Media Pembelajaran yang menarik " Media pembelajaran adalah wahana penyalur pesan dan informasi belajar. Media pembelajaran yang dirancang secara baik akan sangat membantu peserta didik mencapai tujuan pembelajaran. Masing-masing jenis media pembelajaran memilikikarakteristik, kelebihan serta kekurangannya. Itulah sebabnya maka perlu adanya perencanaan yang sistematis untuk penggunaan media pembelajaran. Pengembangan media pembelajaran hendaknya memenuhi prinsip VISUALS (Visible, Interesting, Simple, Useful, Accurate, Legitimate, Structured) dalam perencanaan sistematik untuk penggunaan media."

[2] Menurut Wawan Saputra, Bambang Eka Purnama, 2012, Journal Speed - Sentra Penelitian Engineering dan Edukasi - Volume 4 No 2 - 2012 ijns.org yang berjudul Pengembangan Multimedia Pembelajaran Interaktif Untuk Mata Kuliah Organisasi Komputer "Pada Sistem pembelajaran yang lebih inovatif dan interaktif, pengajar akan selalu dituntut untuk kreatif inovatif dalam mencari terobosan pembelajaran mampu mengabungkan antara text, gambar, audio, musik, animasi gambar atau video dalam satu kesatuan yang saling mendukung guna tercapainya tujuan pembelajaran mampu menimbulkan rasa senang selama proses belajar mengajar berlangsung. Hal ini akan menambah motivasi mahasiswa selama proses belajar mengajar hingga didapatkan tujuan pembelajaran yang maksimal"

[3] Menurut Daniel Valentinus Simanjuntak , 2014, Jurnal Pelita Informatika Budi Darma , Volume : VI, Nomor: 3, April 2014 yang berjudul Penerapan Pencarian Data Numerik Menggunakan Metode Pencarian Relatif (HASH SEARCH) Pada Aplikasi Komputer "Proses pencarian data numerik komputer dilakukan dengan mnginput data lalu diproses dengan cara menampilkan tahaptahap penempatan dan pencarian secara langkah demi langkah untuk setiap data yang di-input. Dengan adanya Metode Relatif Hash Search pencarian data menjadi mudah untuk mencari data numerik pada komputer ".

\subsection{Metoda Pencarian Relatif (Hash Search)}

Fungsi Hash ini menyebabkan data yang tersimpan dalam Tabel Hash memiliki 2 jenis alamat (address) yaitu,

1. Home Address, adalah lokasi (address) yang diperoleh dengan menggunakan Fungsi Hash.

2. Real (Physical) Address, adalah lokasi (address) dimana data tersimpan dalam tabel. Metoda pencarian Relatif (Hash Search) terdiri dari 2 macam yaitu,

1. Hash Tertutup (Closed Hash)

2. Hash Terbuka (Open Hash)

\subsubsection{Hash Tertutup (Closed Hash)}

Hash Tertutup (Closed Hash) didefinisikan sebagai cara Hash dimana data langsung disimpan dalam tabel Hash dengan ukuran tabel tertentu (dapat ditentukan sendiri). Fungsi Hash tersebut dapat didefinisikan sebagai berikut, :

Rumus 1. Fungsi Hash

$\mathrm{H}(\mathrm{X})=(\mathrm{X}$ mod [ukuran tabel] +1$)$

Keterangan :

dengan $: X=$ nilai data ;

$\mathrm{H}(\mathrm{X})$ = hasil fungsi Hash.

Dalam penerapan fungsi Hash di atas dalam perhitungan, terdapat kemungkinan beberapa data memiliki hasil fungsi Hash yang sama. Hal ini menyebabkan terjadinya tabrakan (collision) pada saat penempatan data. Tabrakan (collision) dapat diatasi dengan menggunakan beberapa strategi antara lain,

1. Resolusi Linier (Linear Resolution)

2. Overflow

3. Double Hashing

\subsubsection{Resolusi Linier (Linear Resolution)}

Strategi ini mengatasi tabrakan (collision) dengan cara mencari lokasi lain sebagai tempat dari data yang mengalami tabrakan (collision) dengan menghitung nilai fungsi Hash yang baru (Rehashing) dengan menggunakan rumus berikut,

Rumus 2. Resolusi Linear $h^{\prime}(X)=\left(h_{i-1}^{\prime}(X)+1\right)$ mod [ukuran tabel] +1$)$ Keterangan :

h'i $(X)=$ alamat relatif yang dihasilkan pada proses perhitungan awal

\subsubsection{Overflow}

Strategi ini mengatasi / mengurangi tabrakan (collision) dengan cara membagi tabel menjadi 2 buah, yaitu tabel utama dan tabel overflow dengan ketentuan ukuran tabel utama lebih besar daripada ukuran tabel overflow.

Cara penempatan data pada tabel utama dilakukan dengan menggunakan fungsi Hash. Jika terjadi tabrakan (collision), maka data ditempatkan pada tabel overflow. Cara penempatan data pada tabel overflow dapat dilakukan dengan cara sekuensial atau menggunakan fungsi Hash yang baru. Jika tabel overflow telah penuh, maka data yang masuk ke dalam tabel overflow akan ditolak.

\subsubsection{Double Hashing}

Strategi Double Hashing ini hampir mirip dengan strategi Overflow, yaitu dengan menggunakan dua buah tabel sebagai tempat pengisian data. Perbedaannya adalah strategi ini 
menggunakan dua buah tabel yang sama besar ukurannya. Proses penempatan dan pencarian data untuk strategi ini juga sama persis dengan strategi overflow.

\subsection{SIMULASI}

Simulasi mempelajari atau memprediksi sesuatu yang belum terjadi dengan cara meniru atau membuat model sistem yang dipelajari dan selanjutnya mengadakan eksperimen secara Numeric dengan menggunakan komputer.

\section{METODOLOGI PENELITIAN}

Secara umum, tahap-tahap penelitian dari awal hingga akhir dapat digambarkan dalam diagram alir dibawah ini. Diagram ini memperlihatkan proses penelitian secara keseluruhan.

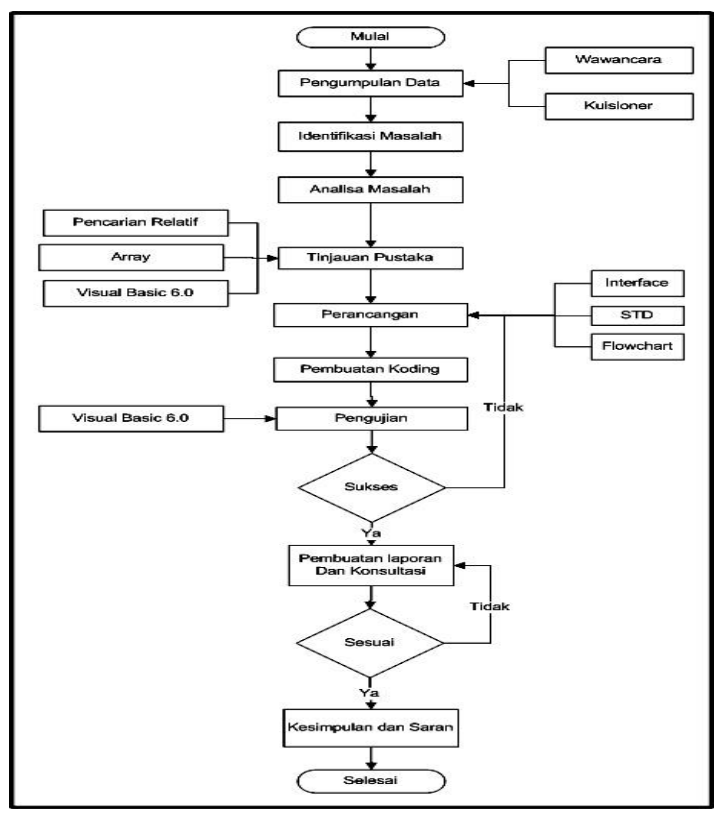

Gambar 1 Diagram Alir Penelitian

\section{ANALISA DAN PERANCANGAN APLIKASI}

\subsection{Analisa Metode Pencarian Relatif}

Metoda pencarian Relatif (Hash Search) in hampir mirip dengan metoda pencarian langsung (Direct Search), yaitu dengan menggunakan rumus tertentu baik pada saat penempatan maupun pencarian data. Pencarian Relatif (Hash Search) memiliki efisiensi penggunaan tempat yang lebih baik daripada pencarian langsung (Direct Search).

Fungsi operasi modulo (mod) ini sering disebut sebagai Fungsi Hash dan tempat penampungan data disebut Tabel Hash. Fungsi Hash bukan merupakan fungsi satu - satu seperti fungsi bagi dari metoda pencarian Langsung (Direct Search) sehingga ada kemungkinan beberapa data memiliki hasil fungsi yang sama. Hal ini mengakibatkan terjadinya tabrakan (collision) pada saat penempatan data ke dalam tabel sehingga diperlukan strategi untuk mengatasi tabrakan (collision) ini. Strategi untuk mengatasi tabrakan (collision) ini ada bermacam - macam dan masing - masing memiliki kelebihan dan kekurangannya masing - masing.

\subsection{Penentuan Metode}

Metoda Pencarian Relatif (Hash Search) Dapat Dibagi Menjadi Beberapa Proses Berikut:

1. Proses pengecekan input data.

2. Proses penempatan data untuk metoda : Hash Tertutup (Close Hash) dengan strategi strategi untuk mengatasi tabrakan (collision) yaitu Resolusi Linier (Linear Resolution), Overflow dan Double Hashing.

3. Proses pencarian data untuk metoda : Hash Tertutup (Close Hash) dengan strategi strategi untuk mengatasi tabrakan (collision) yaitu Resolusi Linier (Linear Resolution), Overflow dan Double Hashing.

\subsection{Perancangan Aplikasi}

Aplikasi ini dirancang dengan beberapa tahapan yaitu tahapan perancangan flowchart proses aplikasi, rancangan hierarki menu aplikasi, rancangan tampilan menu utama dan rancangan alur proses perhitungan aplikasi.

\section{Rancangan Hirarki Menu}

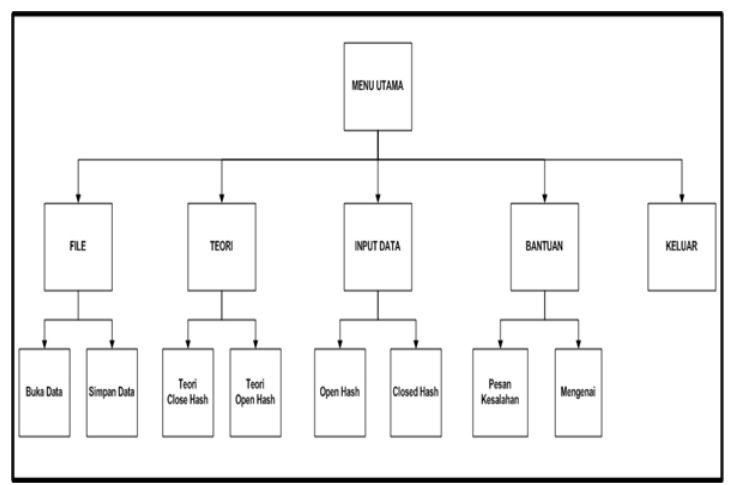

Gambar 2. Rancangan Hirarki Menu Aplikasi

2. Rancangan Tampilan Menu Utama

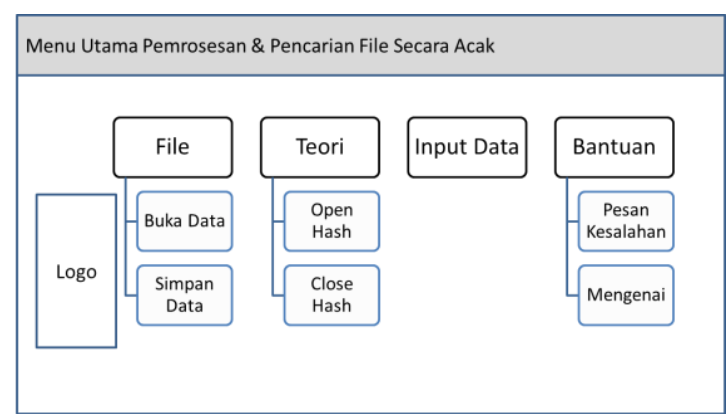

Gambar 3. Rancangan Tampilan Menu Utama 


\section{Rancangan Alur Proses Perhitungan}

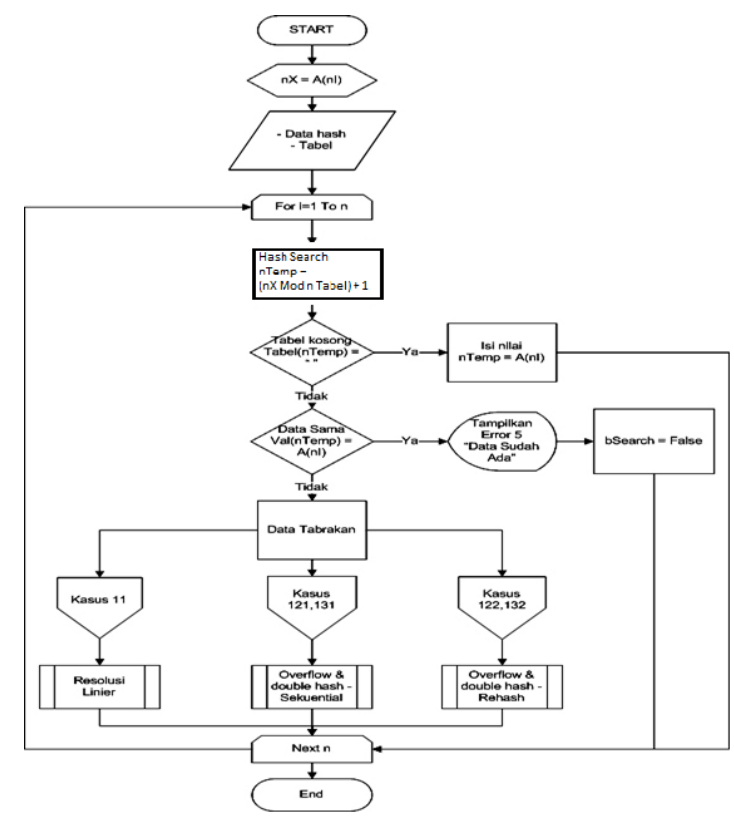

Gambar 4. Rancangan Alur Proses Perhitungan

\section{Rancangan Alur Proses Perhitungan Metode Division Remainder}

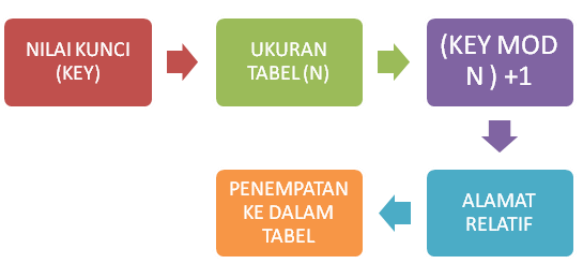

Gambar 5. Alur Proses Metode Division Remainder

Contoh kasus : diketahui ada 8 data dengan ukuran tabel adalah 11, dengan nilai sebagai berikut : $3,6,8,29,37,9,11,20$. Carilah alamat relatifnya dan bagaimana penempatannya ke dalam suatu tabel. Penyelesaian :

Tabel 1. Proses Perhitungan Metode Division Remainder

\begin{tabular}{|l|c|}
\hline PERHITUNGAN & ALAMAT RELATIF \\
\hline$(3 \bmod 11)+1$ & 4 \\
\hline$(6 \bmod 11)+1$ & 7 \\
\hline$(8 \bmod 11)+1$ & 9 \\
\hline$(29 \bmod 11)+1$ & 8 \\
\hline$(37 \bmod 11)+1$ & 5 \\
\hline$(9 \bmod 11)+1$ & 10 \\
\hline$(11 \bmod 11)+1$ & 1 \\
\hline$(21 \bmod 11)+1$ & 11 \\
\hline
\end{tabular}

Tabel 2. Penempatan Data Ke Dalam Tabel

\begin{tabular}{|l|l|l|l|l|l|l|l|l|l|l|l|}
\hline INDEKS & $\mathbf{1}$ & $\mathbf{2}$ & $\mathbf{3}$ & $\mathbf{4}$ & $\mathbf{5}$ & $\mathbf{6}$ & $\mathbf{7}$ & $\mathbf{8}$ & $\mathbf{9}$ & $\mathbf{1 0}$ & $\mathbf{1 1}$ \\
\hline KEY & 11 & & & 3 & 37 & & 6 & 29 & 8 & 9 & 21 \\
\hline
\end{tabular}

\section{Rancangan Alur Proses Linear Probing}

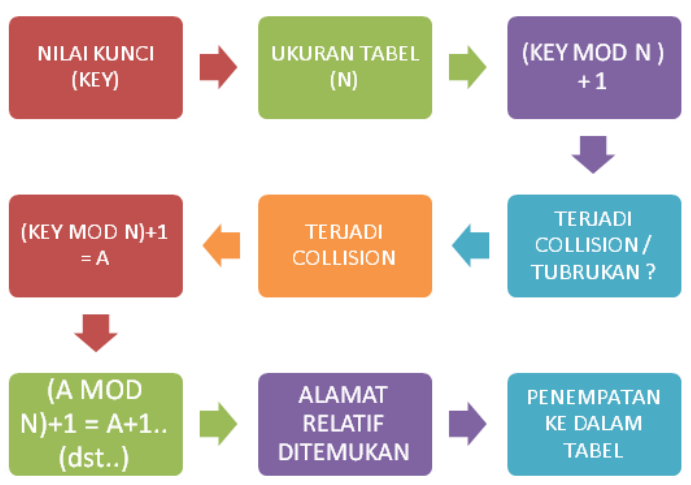

Gambar 6. Alur Proses Linear Probing

Contoh soal : diketahui ukuran tabel 11 dengan jumlah data sebanyak 8 , dengan nilai key : $9,20,4,17,30,46,72,65$. Carilah alamat relatifnya dan bagaimana penempatannya ke dalam tabel.

Penyelesaian :

Tabel 3. Proses Perhitungan Metode Linear Probing

\begin{tabular}{|l|l|}
\hline PERHITUNGAN & ALAMAT RELATIF \\
\hline$(9 \bmod 11)+1$ & 10 \\
\hline$(20 \bmod 11)+1$ & $\begin{array}{l}10\left(^{*} \text { terjadi tubrukan }\right. \\
\text { collision })\end{array}$ \\
\hline$(10 \bmod 11)+1$ & 11 \\
\hline$(4 \bmod 11)+1$ & 5 \\
\hline$(17 \bmod 11)+1$ & 7 \\
\hline$(30 \bmod 11)+1$ & 9 \\
\hline$(46 \bmod 11)+1$ & 3 \\
\hline$(72 \bmod 11)+1$ & 7 \\
\hline$(7 \bmod 11)+1$ & 8 \\
\hline$(65 \bmod 11)+1$ & 2 \\
\hline
\end{tabular}

Tabel 4. Penempatan Data Ke Dalam Tabel

\begin{tabular}{|l|l|l|l|l|l|l|l|l|l|l|l|}
\hline Indeks & $\mathbf{1}$ & $\mathbf{2}$ & $\mathbf{3}$ & $\mathbf{4}$ & $\mathbf{5}$ & $\mathbf{6}$ & $\mathbf{7}$ & $\mathbf{8}$ & $\mathbf{9}$ & $\mathbf{1 0}$ & $\mathbf{1 1}$ \\
\hline Key & & 65 & 46 & & 4 & & 17 & 72 & 30 & 9 & 20 \\
\hline
\end{tabular}

\section{Hasil dan Pembahasan}

Setelah melakukan analisis dan perancangan sistem, langkah selanjutnya adalah uji coba sistem. Uji coba sistem akan mengubah bentuk dari analisis maupun perancangan menjadi bentuk bahasa pemrograman.

\subsection{Ujicoba Program}




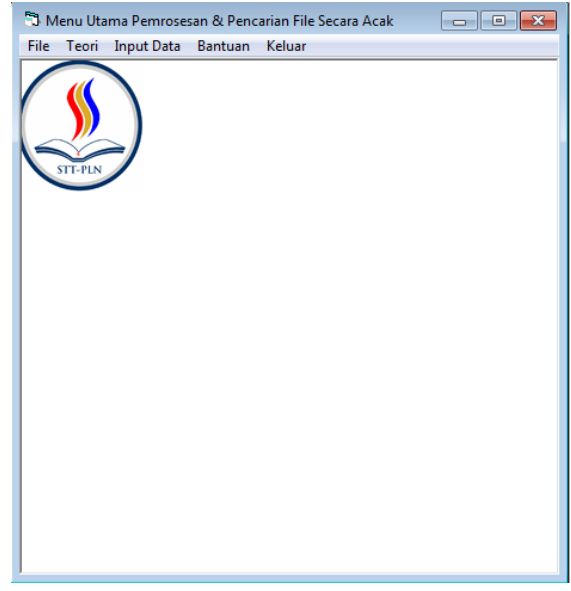

Gambar 7. Tampilan Menu Utama

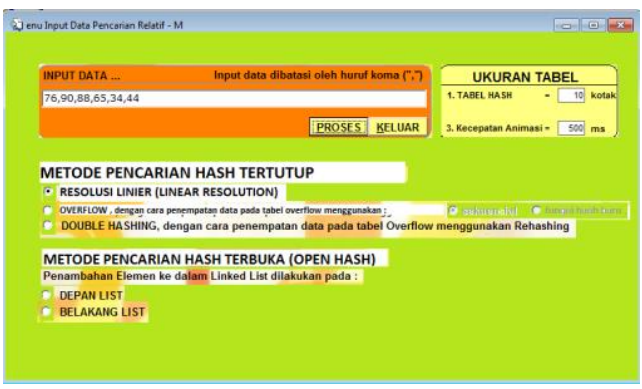

Gambar 8. Tampilan Proses Input Data

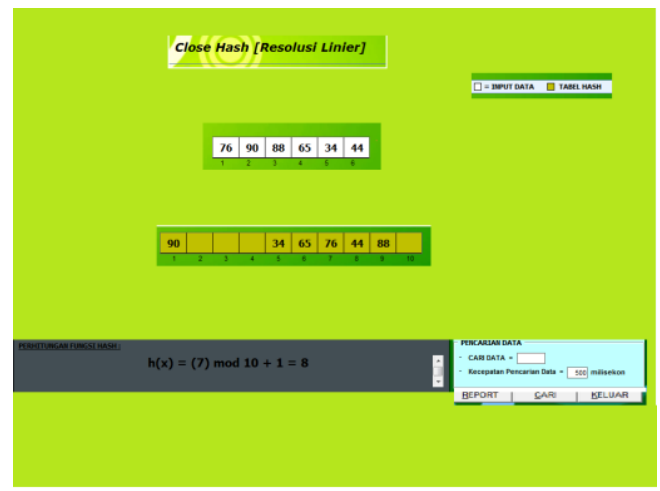

Gambar 9. Tampilan Proses Perhitungan

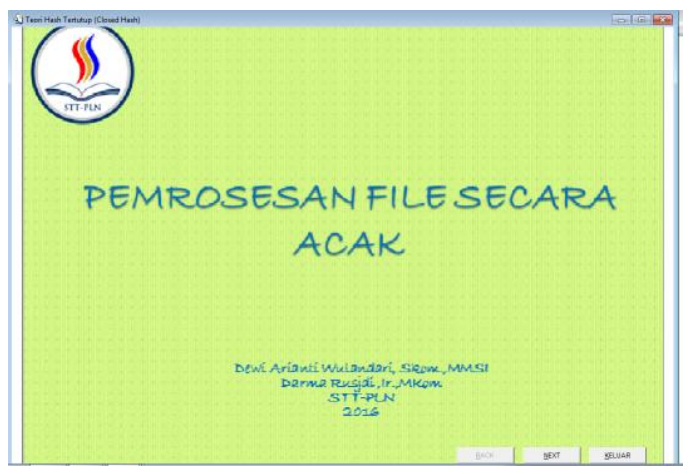

Gambar 10. Tampilan Form Teori

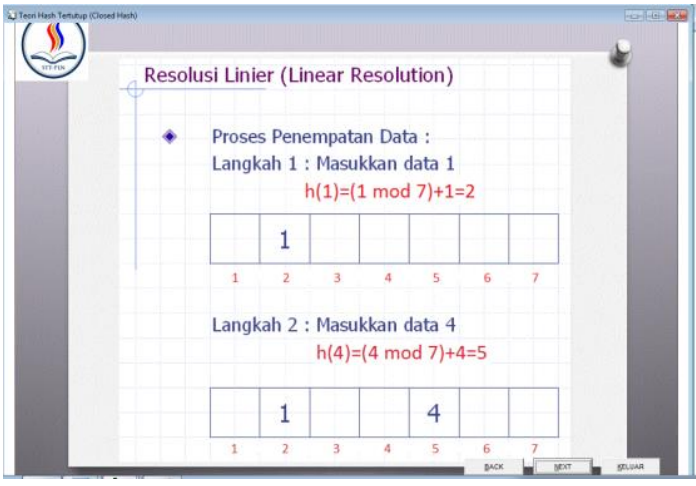

Gambar 11. Tampilan Teori Resolusi Linier

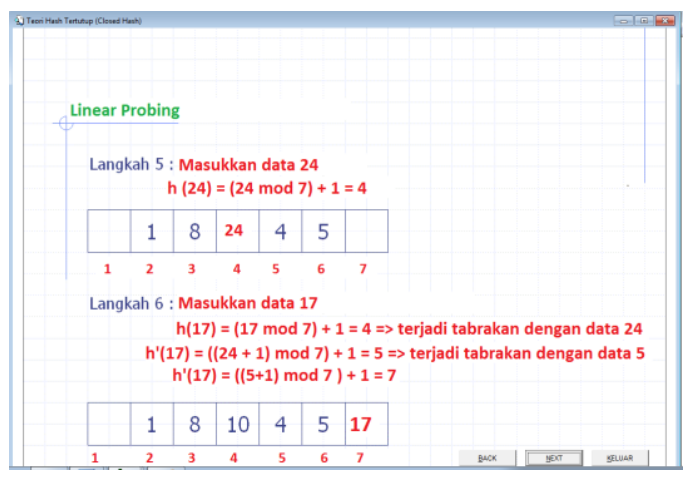

Gambar 12. Tampilan Teori Linear Probing

\subsection{Uji coba Hasil Perhitungan}

PENEMPATAN DATA PADA 'Close Hash [Resolusi Linier]'

Ukuran Tabel Utama $=10$, Fungsi hash $=(h(x) \bmod 10)+1$

Data - Data : 76, 90, 88, 65, 34, 44

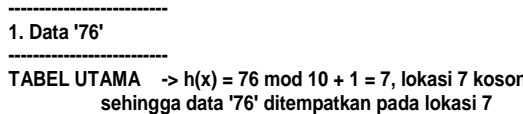

2. Data ' 90 '

TABEL UTAMA $\rightarrow h(x)=90 \bmod 10+1=1$, lokasi 1 kosong sehingga data ' 90 ' ditempatkan pada lokasi 1

\section{Data ' 88 '}

TABEL UTAMA $\rightarrow h(x)=88 \bmod 10+1=9$, lokasi 9 kosong

sehingga data ' 88 ' ditempatkan pada lokasi 9

4. Data ' 65

TABEL UTAMA $\rightarrow h(x)=65 \bmod 10+1=6$, lokasi 6 kosong sehingga data ' 65 ' ditempatkan pada lokasi 6

5. Data ' 34 '

TABEL UTAMA $\rightarrow h(x)=34 \bmod 10+1=5$, lokasi 5 kosong sehingga data ' 34 ' ditempatkan pada lokasi 5

\section{Data ' 44 '}

TABEL UTAMA $\rightarrow \mathrm{h}(\mathrm{x})=44$ mod $10+1=5->$ terjadi tabrakan dengan data ' 34 '

$\rightarrow h(x)=(5) \bmod 10+1=6 \rightarrow$ terjadi tabrakan dengan data ' $65^{\prime}$

$\rightarrow h(x)=(6) \bmod 10+1=7 \rightarrow$ terjadi tabrakan dengan data ' 76 '

$\rightarrow h(x)=(7) \bmod 10+1=8$, lokasi 8 kosong

$>h(x)=(7)$ mod ' 4 ' ditempatkan pada lokasi 8
sehingga data 44 , lokasi 8 kosong 


\subsection{Pembahasan}

Berdasarkan hasil ujicoba diatas, maka dapat diketahui kelebihan dan kelemahan dari aplikasi ini. Adapun kelebihannya adalah :

1. Sistem dapat menampilkan materi pelajaran yang membantu Dosen dalam menyampaikan materi yang diajarkan.

2. Sistem dapat melihatkan tahap demi tahap proses dari metode pencarian relatif.

3. Adanya fasilitas evaluasi apabila terjadi kesalahan dalam sistem maupun untuk kebutuhan pengembangan.

Dan Kelemahan dari aplikasi adalah :

1. Tampilan aplikasi masih belum interaktif.

2. Aplikasi tidak dilengkapi dengan audio.

6. KESIMPULAN

Berdasarkan hasil analisa dan perancangan aplikasi maka dapat diambil beberapa kesimpulan yaitu :

1. Aplikasi ini dirancang melalui empat tahapan yaitu tahapan perancangan flowchart proses aplikasi, rancangan hierarki menu aplikasi, rancangan tampilan menu utama dan rancangan alur proses perhitungan aplikasi.

2. Aplikasi sudah dapat menghasilkan alamat relatif walaupun terjadi tubrukan / collision dan menempatkannya ke dalam tabel.

3. Data yang diinput dan diproses adalah tipe data numerik.

4. Aplikasi dapat membantu dosen dalam menyampaikan materi tentang proses pencarian alamat relatif sehingga mahasiswa dapat dengan mudah untuk memahami dan mengerti tentang materi tersebut khususnya metode division remainder dan metode untuk mengatasi collision (tubrukan) yaitu resolusi linear, overflow dan double hashing

\section{DAFTAR PUSTAKA}

[1] Bambang Hariyanto, 2000, Pengarsipan dan Akses Pada Sistem Berkas, Bandung : Penerbit : Informatika Bandung

[2] Daniel Valentinus Simanjuntak , 2014, Penerapan Pencarian Data Numerik Menggunakan Metode Pencarian Relatif (HASH SEARCH) Pada Aplikasi Komputer, Jurnal Pelita Informatika Budi Darma, Volume : VI, Nomor: 3.

[3] Daryanto , 2011, Media Pembelajaran , Bandung . Penerbit : PT SatuNusa

[4] Dewi Handayani, 2011, Sistem Berkas, Yogyakarta : Penerbit : J\&J Learning

[5] Ramadhan, Arief, 2006, Visual Basic 6.0:36 Jam Belajar Komputer. Jakarta : Penerbit : Elex media komputindo

[6] Sridadi, Bambang. 2009, Pemodelan Dan Simulasi Sistem : Teori Dan Aplikasi.. Bandung : Penerbit Informatika.

[7] Tejo Nurseto , 2011 , Pembuatan Media Pembelajaran yang menarik, Jurnal Ekonomi \& Pendidikan, Volume 8 Nomor 1.

[8] Wahyuni, 2004, Sistem Berkas ,Yogyakarta : Penerbit : Andi Yogyakarta .

[9] Wawan Saputra, Bambang Eka Purnama , 2012, Pengembangan Multimedia Pembelajaran Interaktif Untuk Mata Kuliah Organisasi Komputer, Journal Speed Sentra Penelitian Engineering dan Edukasi Volume 4 No 2 - ijns.org 